\title{
Personnel Management in Local Government Performance - A Case Study of Bo City Council, Sierra Leone
}

\author{
Sahr James Dauda \\ Department of Human Resources Management, Sichuan University of Science \& Engineering, Zigong, China \\ Email address: \\ 1343585293@qq.com \\ To cite this article: \\ Sahr James Dauda. Personnel Management in Local Government Performance - A Case Study of Bo City Council, Sierra Leone. \\ International Journal of Management and Fuzzy Systems. Vol. 5, No. 1, 2019, pp. 21-26. doi: 10.11648/j.ijmfs.20190501.14
}

Received: June 30, 2018; Accepted: February 26, 2019; Published: March 19, 2019

\begin{abstract}
Since the end of the decade-long civil war in 2002, the Sierra Leone government has made a great stride towards the recovery and rebuilding of livelihoods of the people. The government has also gone the extra length to involve the local communities in active decision-making in the government decentralization drive, giving the people the opportunity to directly bring in and implement developments in their own local communities. Witheven the improvements in local councils in Sierra Leone, however, the managerial system of the local councils still require significant further development. It is argued that a sound management system is the most critical tool necessary for organizational development. In other words, well-trained and qualified managerial personnel in Sierra Leone's local councils will lay the basis for successful and sustainable local councils in the country. This article reviewed and examined the role of effective personnel management on the success and sustainability of local councils. The success of a local council is measured in terms of the developments brought, implemented and approved by the local communities. Then sustainability of a local council is measured in the ability of the council to raise revolving funds from the implemented development programs for reinvestment into further development based on the needs hierarchy of the people and their communities. The study discussed the managerial problems encountered by local councils in the course of delivering administrative functions in the local communities. Finally, it highlighted the importance of active personnel management in government decentralization in the delivery of public services towards sustainable community development.
\end{abstract}

Keywords: Personnel Management, Government Decentralization, Local Government, Local Community, Civil War

\section{Introduction}

Sierra Leone is among the poorest countries in the world and its current economic and social infrastructure cannot support meaningful development. Both its economy and standard of life rapidly deteriorated with decades of political uncertainty which eventually led to the civil war in 1991-2000. Towards the end of the civil war, the government focused more on decentralization as a critical reform pathway to full autonomy and development for self-actualization of rural communities. The reform towards decentralized government, which was abolished decades before under the one-party APC (All People's Congress) government, was once again set in motion (The Truth \& Reconciliation Commission, TRC, 2004). As pointed out by Hanlon (2005) and Kieh (2005), the over-centralization of the system of rule that sidelined the majority of the population in decision-making was one of the main causes of the civil war in Sierra Leone. The main argument in support of the establishment of local government is that it helps bring the central government closer to the people. Thus the reestablishment of local government was believed to rapidly rebuild and improve the living standard of the people. This was to be actualized via better resource allocation and the active participation of the citizenry in the process of governance and development planning for local communities. The participation of the citizenry in public affairs can empower and ensure oneness in resolving community problems. Zhou (2002) noted that decentralization was a post-war strategy built to avoid past mistakes by involving local citizens in governance and development planning that influence their livelihood of the people in every form and shape.

In spite of its countless merits, the process of decentralization in Sierra Leone was far slower than ever 
expected, and it was especially the case for the hinterlands. However, with financial and other forms of aid from NGOs (Non-Governmental Organizations) and other agencies (private \& public), a functional modern system of decentralization was eventually set up in Sierra Leone. Since then, the local councils in Sierra Leone have recorded a fast development progress with most local council positions occupied with talented qualified personnel. Also the introduction of staff development planners, internal auditors, monitoring and evaluation officers and procurement officers has improved management and service deliveries with increasing success stories.

\section{Sierra Leone Local Government}

Decentralization brings government closer to the people by expanding its political space and allowing citizen participation in public affairs and government accountability, all of which strengthen the legitimacy of the state (Bardhan $\&$ Mookherjee, 2006).

The political and administrative rule established under the British colonial system divided the country into a colony of two administrative regions - Freetown and the Western Area, and then the Protectorate (or the hinterlands). An elected local government was formed in the colony, with the British governor as the representative on behalf of the British monarchy, the system of indirect rule was implemented to help with the smooth running of the Protectorate. It included traditional chiefs and community heads in creating and maintaining law and order, settling local disputes and collecting revenue. Collected revenue from the protectorate is then used to pay wages and for of community development programs such as building schools, providing water supply, construction of roads and supporting agricultural production. The indirect system of governance was the strategy used to involve the local people in local politics as a training ground for running government functions at town and village tiers after independence. As a protectorate, the people learned how to produce president and many more became involved in politics.

After independence in 1967, the local councils continued to function until 1972 when all was abolished in favor of the central government system of rule. Fanthorpe et al. (2006) stated that the then president Siaka P. Stevens thought that by centralizing (focusing everything in the capital city) government, he could maintain maximum possible control over national economic development. It, however, turned out that such was never realized. In fact by marginalizing the local people from partaking in local governance, their communities ended up been grossly underdeveloped (especially hinterland communities). This was because the central government focused almost entirely on developing the capital city (Freetown), where all important offices (e.g., hospitals, banks, universities, police headquarters, foreign businesses, etc.) were concentrated. This later on led to large-scale migration of the hinterland population to the city in search of better life, education, Medicare and business opportunities. Resulting to overcrowding in the capital city had negative effects on the country. This included overcrowded schools, political instability, disease epidemic outbreaks and high unemployment rate. These were among the factors that later led to the civil unrest, which then degenerated in a violent civil war in the country. Therefore, the re-establishment of local councils in Sierra Leone in 2004 was intended to give the local people a greater say in the governance of their own local communities. It was hoped to reverse the long years of marginalization of rural districts and them regain their place on the political arena. The Sierra Leone People' s Party (SLPP), led by Ahmed Tejan Kabbah, started decentralization in 2002 by restoring local governments and local councils. However, it was not until 2004 that local governments were actually re-established.

The Ministry of Local Government and Rural Development (MLGRD) is the responsible arm of government for local government in Sierra Leone. Local government is comprised of 6 urban councils (Freetown, Bo, Kenema, Makeni, Koidu and Bonthe City Council), 13 district councils and 150 chiefdom councils. The local government body is governed by the Local Government Act (LGA) and not by the Sierra Leone Constitution and has the duty of creating and executing its own by-laws. The Act consolidates amendments and creates provision for decentralization and distribution of the functions, powers and duties of government connected with local councils and provide transparency and accountability in local participation. Chiefdom's, on the other hand, constitute the lowest unit of administration but LGA recognizes the laws and regulations governing chieftaincy and chiefdom administration. The Local Government Act (LGA) provides representation in councils and membership in ward committees for paramount chiefs. The 2004 LGA devolved some 80 specific functions to local governments at the end of 2012. The first functions devolved were environmental health, primary and junior-secondary education, agriculture services, rural water supply, waste management and community development.

The first local council election was held three months after the enactment of the LGA in March 2004, aimed at attaining political stability through democratic election of local councils. As the highest political authority in the local jurisdiction, the local government legislation sets out detailed political framework with respect to free, fair and transparent elections and composition of council members. It states out the qualifications for the positions of the councilor and outlines the procedures for the elections and qualifications of mayoral (urban) and chairperson (rural) positions. The Sierra Leone local government is responsible with the promotion of developmental programs and the welfare of the people in its jurisdiction with resources at its disposal and with financial aids from the central government and other private and NGO agencies. The most notable development achievement of the local councils in the past years includes peace, stability and democratic process. A system of intergovernmental transfers was set in place in 2004 to help oversee the formulation and creation of the local government. Unfortunately, however, the introduction of the new local government faced several major problems. 
Nevertheless, local councils in recent years have been able to deal with the problems by hiring well-trained and qualify staff with the acumen to properly manage service delivery for the development of their respective areas and communities.

\subsection{Local Government Functions}

A major question frequently asked is how the local government helps local communities accomplish developmental programs. Highlighted below are some of the main roles and functions highlights of the local government in community development in Sierra Leone.

It is widely debated and discussed in educational and political arenas that as the mail pillar of decentralization, local government generally fosters peace, stability and community development. Among the more specific roles and functions of the local government highlighted in the debates and discussions are:

\subsubsection{Efficient Resources Allocation}

It is argued that local authorities are more sensitive and up-to-date with local priorities and needs as they are much closer to local communities than the central government and can therefore effectively allocate resources and services most needed in a transparent and accountable way that in turn fosters rapid community development.

\subsubsection{Information Source}

Local council serves as a communication channel between the central government and local communities. The local council is the "direct contact body" by the central government and the local communities in all affairs of the country. It helps disseminate information to the community about government policies and development plans and laws. It also gathers information on the people and development needs and take it back to the central government.

\subsubsection{Responsiveness}

As above, the two-way collection and delivery of information between the central government and local communities always takes much longer time. This is especially the case for the hinterlands with poor road networks, lack of electricity and internet, etc.; making it very difficult to carry emergency supplies in times of need. However, with local council, there can be much faster response to local community needs.

\subsubsection{Local Revenue Maximization}

Local council is believed to be less wasteful as it only deals with development constituencies. Its revenue is mainly from local taxes, fees and sometimes financial aids from the central government and is largely used in community development activities.

\subsubsection{Accountability}

Local communities are better placed to influence local politicians and to be more involved in policy-making at local level than at the national level. One of the advantages of the local council is its size. It is of course smaller than the central government, making it much easier for local community members to be directly able to influence local authorities on matters not managed in the interest of the people.

\subsection{Bo City Council}

Bo, as the second largest city in Sierra Leone, has a population of about 306,000 . Bo City is crowned as the most developed provincial urban milieu in Sierra Leone because of its strong financial, educational and medical status. In 2004, the parliament invoked the Local Government Act to re-establish the Bo City Council with the sole responsibility of managing the city (sometime also known as Bo town). The roles, functions, responsibility and power to pass bylaws by the Bo City Council are drawn from the Local Government Act. The Act also states the terms of local elections and qualifications, where the councilors and mayor of Bo Town are elected every four years by the local people. Despite the efforts of the local government and the government of Sierra Leone, Bo City Council still faces significant personnel problems in executing local government functions such as insourcing, planning, training, recruitment and maintaining staff.

\subsection{Council Management Obstacles}

Bo City Council, like any other local council in Sierra Leone, does share the same common problems. Although the re-establishment of local government after the decade-long civil war was viewed as a sign of development, it was met with a whole lot of problems. Some of the problems faced by the Bo local council are highlighted as below:

\subsubsection{Limited Revenue}

Bo city council has limited revenue and its mobilized budget for local development is small. With the ending of the civil war, the government was most preoccupied with fostering peace and security with the borders of Sierra Leone. Thus the sole source of finance of Bo City Council was tax, fines and aids from NGOs and the private sector. Even so, the revenue collected was grossly insufficient for even payment of staff wages, let alone the execution of the massive developmental needs of the city.

\subsubsection{High Corruption}

The level of corruption in Sierra Leone is the highest in the world. Bo City Council, like all other city councils in the country, is endemically corrupt. Staff employment is highly political, coupled with crooked recruitment officers who often call for high kickbacks for recruitment. The end result of such practice is highly unqualified and unskilled staffs that run the council in every unprofessional way imaginable.

\subsubsection{Faulty Administrative/Management Structure}

This is a major problem affecting Bo City Council. The re-establishment of local government meant the transfer of power, duties, responsibilities and resources to local communities. The failure to recognize this critical delectable function by the central government has undercut the 
effectiveness and efficiency of the administrative and management roles of the council. Unfortunately, most of the elected officials and personnel in the Bo City Council lack the education it takes for good governance. The political influence mars the managerial skills and makes it very difficult, if not impossible, for the city council to effectively manage and administer its functions.

\subsubsection{Low Participation}

The most important function of any city council is bringing government closer to the local community and cultivating talents at grassroots level to governance their local communities. However, the decentralization process is increasingly less participatory. Local communities have little or no knowledge about the work of the local council. The local people think their roles and responsibilities end with the election of councilors and that it then the responsibility of the elected councilors to work to develop the local communities. This laisser-faire attitude on the side of local community members gives the council officials the freehand to wantonly mismanage whatever little resources that are available.

\subsubsection{Poor Work Condition}

This is a critical issue facing local councils across Sierra Leone, especially in the hinterland provinces. Officials are often unwilling to work in remote areas without basic amenities such as water supply, electricity, tarred roads and medical care. The willing or available few are less educated, poorly trained, unskilled and least motivated for any effective discharge of duties.

\section{Challenges Faced by Councilors}

A councilor is an elected member who governs a city, in the case of Sierra Leone, a town. The roles and responsibilities of a councilor are to help with the development of local communities through popular participation. The councilor is the intermediary between the central government and the community people. Since the re-establishment of local government in Sierra Leone, the implementation of the new government structure has been full of challenges. Among the most significant of these challenges is the understanding and specification of the roles and responsibilities of councilors, which challenge has set so much confusion about the very concept of local government to the people. Councilors of the Bo City Council have been facing a series of difficult challenges since the re-establishment of local government in the country. Some of these challenges are listed as follows:

\subsection{Role Misconception}

One of the main problems encountered by Bo City Councilor is gross misconception of their role in the constituency. The city councilors are widely believed to be there to sponsor weddings, funerals or help with domestic expenses. Thus when the councilors fail to deliver such, complain grow that their own elected councilors are not for them and therefore refuse to cooperate with the councilors on real development issues such as providing pipe-borne water system, hospitals/clinics or road networks.

\subsection{Political Experience}

Many councilors do not have political experience and therefore do not know their role as councilors. Some even have no time to read the Local Council Act that establishes the local council structure. Where read, the low level of education limits their understanding and grasping of the running of local councils which massively affect the effective work of the councilors. The lack of political experience is a limiting barrier to councilors, finding it difficult to create and deal with development issues or to challenge and criticize the central government for things done not in favor of the people.

\subsection{Development Plan Execution}

Another problem encountered by local councilors is the successful execution of developmental plans and policies. There are always wonderful policies and developmental plans such as building hospitals, schools and roads. Although all of these help local communities, it always takes long periods for actualization. In some cases in fact, such projects are never ever actualized since the councilors lack the knowhow for successful implement plans and policies.

\subsection{Law Execution}

Most local councilors, especially the ones at the Bo City Council, find it very difficult in execute the laws due to inconsistencies in the Local Government Act (bylaws) and the National Laws (the constitution). For example, the Local Government Act does not explain in detail the relationship between local council and chieftaincy, only stating the role and functions of each. Although by law chiefdom is subordinate to local council, most traditional chiefs fail to accepted this hierarchy as the Act transfers several sources of revenue previously controlled by the chiefs to the local council, including local tax, fees and licenses.

\section{Bo City Council Personnel Management}

Personnel management is that part of an organization that is primarily concerned with managing human resources. It deals with planning, organizing, compensating, integrating, promoting and stimulating competent workforce to make the fullest contribution towards achieving organizational goals. A well-organized and managed personnel enhances performance and increases productivity within the organization. Management and political scholars have discussed and written articles about the relationship between local government and personnel management and sought answers on how personnel management can help solve some of the problems faced by local governments. It is concluded that personnel management in local government helps to mobilize and organize human and material resources through effective management of the 
human resources wing of the council. This provides elected officials and local government staff with detailed information about management operations and personnel issues. It has become the primary ingredient in local government sectors as elected Mayors and Councilors manage and deal with hired workers and the local people in a more professional manner. However, personnel management achievement of local council goals is frequently interrupted at Bo City Council.

\subsection{Efficient Personnel Management Benefits}

Proper personnel management enhances local government administration whereby it effectively discharges its foundation roles and functions for local community development. The fast development of Bo City Council depends to a large extent on improvements in its management system. Some critical functions of personnel management that must be executed before any actualization of improvements in city councils are listed as below:

\subsubsection{Sound Managerial System}

This deals with staffing, planning, coordinating, budgeting, recruiting, reporting and directing organizations. Managers regulate and effectively plan the day-to-day operations of organizations and see that organizational goals are met. A sound managerial system in local councils can ensure the development of city council offices and departments. This requires modernizing the work environment, recruiting qualified personnel with the foresight to initiate realistic development projects, financial planning and budgeting for both short-term and long-term development goals, etc. In other words, a sound managerial system is the cornerstone for the actualization of local council goals.

\subsubsection{Proper Planning}

Another critical personnel management issue in any institution is maintaining and motivating the workforce. This is achievable by drawing simple straight bonus-malus systems for good-bad serves delivery to the communities served by city councils. Clearly spelling out the short-term and long-term plans of the institution and outlining the roles, functions and responsibilities of the various departments is critical for a successful organization. Through proper planning for wage scales, union issues, labor markets, budgets and finances, the developmental of local communities can be ensured. Proper planning by local city council officials makes it possible to anticipate future challenges local councils are likely to face, and therefore solutions are sought before any such challenges actually arise.

\subsubsection{Skills Enhancement}

Most city council officials have low educational background, usually with no work ethics and experience. With on-the-job training, however, the council staff can be exposed to modern personnel enhancement technology such as the use of computers, telephones, emails, fax machine, etc. Such training improve staff skills and capacity to perform on the job that will in turn make city councils meet goals they are set up to execute.

\subsubsection{Performance Appraisal}

Appraisal is a motivation factor, especially if based on the bonus-malus system. Appraisal is the evaluation of the workforce on the work done towards achieving organizational goals. Councilors can use appraisal systems to review and analyze the strengths and weaknesses of local council staff and for promotion. Performance appraisal encourages local community workers to be devoted and hard-working. In the bonus-malus system, hard-working workers are rewarded (e.g., promotions), whereas non-denoted workers are punished (e.g., queries). Performance appraisal functions of local council personnel managers increase the productivity and development of local city councils. With appraisals, there is the tendency for the staff to put more effort, time and energy into the work and more willing for transfers.

\subsection{Personnel Managers Challenges}

The office of personnel manager in local governments is specially created to help promote effective management at grassroots level. Personnel managers at local government or grassroots level in Sierra Leone face more challenges than in their counterparts in the private sector. This is because the responsibility of the public sector is to render service to the citizenry, and not seeking profits. The efforts of the Bo City Council to transform and improve its management structure are perpetually challenged as listed below:

\subsubsection{Inexperienced Workforce}

Personnel managers in the Bo City Council have to work with a very inexperienced personnel they themselves recruit. This boils down to the adage of having square pegs in round holes. Most of the workers are appointed or assigned to positions without formal education of the roles and responsibilities of the city council. It therefore makes it very difficult for the people in charge to properly execute and assign duties to the staff under their authority.

\subsubsection{Low Training}

Having workers regularly trained can have great impact on the output of the organization. However, local governments, especially the Bo City Council, have significant challenges with staff training. The Bo City Council, like all other local councils in Sierra Leone, has a very limited budget and little financial aid from the central government or NGOs and can therefore train its staff on the job. The councilor or mayor naturally prefers to dispense funds on development programs rather on staff training. When training programs are sometimes sponsored by outside bodies, only close associates (relatives and friends) are selected. This is done in the hope that upon completion, only the trained associates are granted promotions.

\subsubsection{Non-Motivation}

The satisfaction of the staff is a critical motivation factor for on-the-job performance and the will to transfer. Taylor (2008) noted that employee dissatisfaction is the main reason for quitting of jobs. In Bo City Council, the staff is less motivated in terms salary scale, work environment, office equipment 
availability (Computers, Telephone, Electricity, fax machines, etc.). Workers always find this kind of environment very boring and therefore gradually become less motivated that eventually lead to switch overs to other jobs.

\subsubsection{High Illiteracy}

Sierra Leone still has a huge up-hill fight against illiteracy, especially among the female population in the hinterland who are largely denied education. The human resources department of Bo City Council is struggling with the huge illiteracy among its staff. Most of the staff members cannot read or write, which makes very hard the dissemination of information, planning training programs and staff promotion appraisals.

\subsubsection{Lack of High-Tech}

It is true that a high rate of illiteracy in the Bo City Council discourages the introduction of high-tech in local council offices. This is because a large fraction of the staff has no formal education and is inexperienced in the use of computers and other complex office equipment.

\section{Perspective Conclusions}

In spite of the re-establishment of local government system and the benefits it is supposed to bring, especially in terms of local community development via popular participation and closeness to central government, it is safe to say that the Sierra Leone scenario has failed to bring the desired aspirations of the establishment of local councils. Local community development has got firmly stock in theory, especially in rural areas where local councils have failed to develop even basic services such as health centers and educational institutions for the people. The councils are deeply corrupt and the provinces are seeing increasing levels of unemployment, lack of training facilities for unskilled youths, etc. Indeed, the Bo City Council is hampered with the inefficiency of the Personnel management department (or the Human resources management department), grossly failing specifically in capacity building and the creation of conducive work environment. The hiring of unqualified staff with no educational or basic skills limits the capacity of the local council to best serve the communities under its jurisdiction.

Nevertheless, there is a vast repository of literature on the impact of local government on local community development. Remarkable among the conclusions in these studies are the suggestions that modern and advanced managerial system is required by local councils to realize community development. Unfortunately, little is done on the degree to which personnel management can enhance local government to achieve any such goals. In conclusion, the central governments should emphasize social/cooperate accountability in local council systems by building active and effective managerial systems. Of all the tasks of management, human resources management is central to the achievement of organizational goals.

\section{Acknowledgements}

I would like to show my gratitude to my friends and colleagues who provided insight and expertise that greatly assisted the research and I would also like to show my gratitude to my professor Mr. Xiao at Sichuan University of Science and Engineering and to my uncle Doc. Moiwo for sharing their pearls of wisdom with me during the course of this research.

\section{References}

[1] Whou, Yongmei. 2009. Decentralization, Democracy, and development Recent Experience from Sierra Leone. World Bank: Washington DC.

[2] http://www.commonwealthgovernance.org/countries/africa/sie rra_leone/local-government/

[3] Zhou, Yongmei and Ye Zhang (2009). "Civic Engagement in Local Governance" in Yongmei Zhou (ed.) Decentralization, Democracy, and development Recent Experience from Sierra Leone. World Bank: Washington DC.

[4] https://www.urban.org/research/publication/local-governmentdiscretion-and-accountability-sierra-leone/view/full_report

[5] Richards, Paul (1996) Fighting for the Rainforest: War, Youth and Resources in Sierra Leone, Oxford: James Currey.

[6] http://www.studymode.com/essays/Human-Resource-Manage ment-For-The-Local-167438html

[7] Mahieu S, Yilmaz S. 2010. Local government discretion and accountability in Burkina Faso. Public Administration and Development 30 (5):329-344.

[8] Labonte, M. 2012. "From patronage to peace building? Elite capture and governance from below in Sierra Leone" African Affairs111, 442: 90-115.

[9] Abdullah, Ibrahim ed. (2004) Between democracy and terror: the Sierra Leone civil war, Dakar, Senegal: CODESRIA.

[10] Edwards, Ben and Jamie Boex (2013). A Local Public Sector Profile for Sierra Leone: A post-Conflict Transition Towards Decentralization. Washington: The Urban Institute.

[11] Reginald UgaddanSung Min Park (July 2018) Do Trustful Leadership, Organizational Justice, and Motivation Influence Whistle-Blowing Intention? Evidence From Federal Employees.

[12] Hyung-Woo Lee (Jul 2018) Moderators of the Motivational Effects of Performance Management: A Comprehensive Exploration Based on Expectancy Theory.

[13] Tae Kyu WangRalph Brower (July 2018) Job Satisfaction Among Federal Employees: The Role of Employee Interaction With Work Environment.

[14] Helen H. Yu (Apr 2018) Gender and Public Agency Hiring: An Exploratory Analysis of Recruitment Practices in Federal Law Enforcement.

[15] Performance Measurement in Local Government By Daniel Elroi, Elroi Consulting, Inc.

https://r.search.yahoo.com/_ylt=A0geK.KM63Nb_RMACUB XNyoA; ylu=X3oDMTEycnM3djFsBGNvbG8DY mYxBHB vcwMyBHZ0aWQDQjQ4NTNfMQRzZWMDc3I-/RV=2/RE $=1534352397 / \mathrm{RO}=10 / \mathrm{RU}=\mathrm{http} \% 3 \mathrm{a} \% 2 \mathrm{f} \% 2 \mathrm{fwww}$.esri.com $\% 2 \mathrm{f}$ news $\% 2$ farcuser $\% 2$ f0205\%2fperformance.html/RK=2/RS=eA 18a4zYT6_FX3kNjEvnbo4PT4U- 